\title{
Response of groundnut (Arachis hypogaea L.) genotypes to combined application of phosphorus and foliar zinc fertilizers in Central Tigray, Ethiopia
}

\author{
Hintsa Meresa ${ }^{1 *}$, Dereje Assefa ${ }^{2}$ and Yemane Tsehaye ${ }^{2}$
}

\begin{abstract}
Background: Adequate phosphorus (P) and foliar zinc ( $\mathrm{Zn})$ in groundnut required for obtaining $\mathrm{Zn}$-enriched grain and optimum yield. However, it was very low in the area. Due to that objective of the study was to investigate the response of groundnut genotypes to combined application of phosphorus and zinc on yield and nutritional contents. A field experiment was conducted at Sheka-Tekli in 2017/18 cropping season.

Methods: The treatments were consisted of three groundnut genotypes (ICGV00308, ICGV91114 and Sedi) as main plot and four combined PZn fertilizer levels (00), $10 \mathrm{~kg}$ P/ha $+0.50 \mathrm{~g} \mathrm{Zn/L,} 20 \mathrm{~kg} P / \mathrm{ha}+1 \mathrm{~g} \mathrm{Zn/L} \mathrm{and} 30 \mathrm{~kg} \mathrm{P/}$ $\mathrm{ha}+1.5 \mathrm{~g} \mathrm{Zn/L}$ as sub plot were assigned in split plot design with tree replications.

Result: The result indicated that yield and yield components respond significantly to the main and interaction effects. The highest significant seed yield (2529 kg/ha) and protein content (37.79\%) were obtained in response to the application of $\mathrm{P}_{30} \mathrm{Zn} \mathrm{n}_{1.5}$ fertilizer on sedi variety in the loamy sand soil. The percentage of crude protein and fat content had significantly affected by interaction components. Most of the yield component traits showed strong positive correlation with seed yield. While the lowest seed yield was recorded from ICGV00308 without fertilizer. The highest fat content (43.95\%) was gained from genotype ICGV00308 at $P_{30} Z n_{1.5}$ fertilizer. From the interaction of sedi with $P_{30} Z n_{1.5}$ fertilizer was recorded highest protein content. Based on economic analysis the highest MRR (380.58\%) was obtained from ICGV00308 genotype at $\mathrm{P}_{10} \mathrm{Zn}_{0.5}$ fertilizer.
\end{abstract}

Conclusion: From the result of the study, application of PZn fertilizer increases seed yield of groundnut. Therefore, based on the MRR result ICGV00308 genotype at $\mathrm{P}_{10} \mathrm{Zn}_{0.5}$ fertilizer was optimum for groundnut production in the study area and similar agro-ecologies.

Keywords: Groundnut genotypes, P, Foliar spraying Zn, Sheka-Tekli

\section{Background}

Groundnut (Arachis hypogaea L.), also known as peanut, earthnut, monkey-nut is a self-pollinating, indeterminate, annual herbaceous crop (Adinya et al. 2010). Its seed contain about $50 \%$ of edible oil and the remaining

\footnotetext{
*Correspondence: hintsa1982@gmail.com

${ }^{1}$ Tigray Agricultural Research Institute, Abergelle Agricultural Research Center, Tigray, P. O. Box 44, Abi-Adi, Ethiopia

Full list of author information is available at the end of the article
}

$50 \%$ of the seed has high quality protein $(36.4 \%)$, carbohydrate in the range (6-24.9\%), minerals and vitamin (Baraker et al. 2017).

Ethiopia retains varying climatic conditions results in the cultivation of a wide range oil crops including groundnut. Groundnut was introduced to Ethiopia in the early 1920s from Eritrea to Hararghe by the Italian travelers (Daniel 2009). Presently it accounts $13.64 \%$ of total oil seed produced. 
The lowland areas of Ethiopia have great potential for increased oil crop production including groundnut. Groundnut is one of the five widely cultivated oil seed crops in Ethiopia. It uses for oil extraction, makes important cash income for several small-scale producers and foreign exchange earnings through export for the country (Gezahagn 2013). The estimated production area and yield of groundnut in Ethiopia in 2015/2016 cropping season were $75,255.73$ ha and $1151,800.37$ quintals, respectively (CSA 2014).

In Tanqua-Abergelle district, Low macro and micronutrients, moisture, lack of improved varieties and poor agronomic practices are considered as major constraints of groundnut yield. Despite the indicated challenges through application of good management practices, the potential for increasing productivity and enhancing quality of groundnut in the region and specifically at the study area (Sheka-Tekli) is high; such as using improved varieties and through correcting essential deficient soil nutrients such as phosphorus and zinc. For example, studies made in Egypt showed that application of P-fertilizer and foliar spray of $\mathrm{Zn}$ in a poor soil significantly improved seed yield and quality contents (oil and protein \%), Gobarah et al. (2006) and Dordas (2008) also demonstrated the role of $\mathrm{P}$ in improving host-resistances and toxicity of $\mathrm{Zn}$ to several pathogens, respectively. These justifies the need to investigate and understand how the different groundnut genotypes were interact to the combined rates of $\mathrm{P}$ and $\mathrm{Zn}$ fertilizers on yield, nutritional content and profitability of groundnut production.

\section{Materials and methods}

In Tanqua-Abergelle district: Low macro and micronutrients, moisture, lack of improved varieties and poor agronomic practices are considered as major constraints of groundnut yield.

The study area (Sheka-Tekli) is considered as one of the most important places in Tanqua-Abergelle district, Tigray Region (Northern Ethiopia) for the production of groundnut. The study area lies between a latitude of $13^{\circ} 33^{\prime} 08^{\prime \prime} \mathrm{N}$, longitudes $39^{\circ} 02^{\prime} 8^{\prime \prime} \mathrm{E}$ and elevation of $1516 \mathrm{~m}$, respectively. The climate and weather conditions of Tanqua-Abergelle district belong to the sub-tropics and monsoon weather prevails throughout the year. The mean annual rainfall of the area is varying from $350 \mathrm{~mm}$ to $700 \mathrm{~mm}$ with minimum and maximum temperature of $24{ }^{\circ} \mathrm{C}$ and $41^{\circ} \mathrm{C}$, respectively.

Pre-planting soil samples was collected from five spots from the experimental field before planting diagonally at a depth of $0-30 \mathrm{~cm}$ (which is the estimated root depth of groundnut) using an auger. The composite sample was prepared by mixing all the sample had subjected to selected physicochemical properties.
Mainly: texture of the soil by hydrometer (Bouyoucos 1962), soil pH by pH meter (Rhoades 1982), electrical conductivity by $1: 2.5$ water suspension, total nitrogen by Kjeldahl, (Bremner and Mulvaney 1982), available phosphorus by Olsen method, (Olsen et al. 1954), organic carbon (Walkley and Black 1934) by volumetric, cation exchange capacity by ammonium acetate method were analyzed in Mekelle soil laboratory and available $\mathrm{Zn}$ by atomic absorption spectrophotometer at ezana analytical laboratory are given in (Table 1). The groundnut genotypes: ICGV00308, ICGV91114 and Sedi (standard check) were used for planting materials.

Fertilizer treatment phosphorus as triple super phosphate (TSP) and zinc sulphate $\left(\mathrm{ZnSo}_{4} 7 \mathrm{H}_{2} \mathrm{O}\right)$ was used as a source of $\mathrm{P}$ and $\mathrm{Zn}$ fertilizer, respectively. The phosphorus fertilizer was applied in the soil at time of sowing. Whereas, foliar sparing with zinc was done at flowering stage with the rate of $952 \mathrm{~L} / \mathrm{ha}$ of water (Gobarah et al. 2006).

The experimental design was split plot with groundnut genotypes (ICGV00308, ICGV9111, and Sedi main plot and four combination of $(\mathrm{P}+\mathrm{Zn})$ fertilizers $\left(\mathrm{P}_{0} \mathrm{Zn}\right.$, $\left(10 \mathrm{~kg} \mathrm{P} / \mathrm{ha}+0.50 \mathrm{~g} \mathrm{Zn} / \mathrm{L}\left(\mathrm{P}_{10} \mathrm{Zn}_{0.5}\right), 20 \mathrm{~kg}\right.$ $\mathrm{P} / \mathrm{ha}+1 \mathrm{~g} \mathrm{Zn} / \mathrm{L}\left(\mathrm{P}_{20} \mathrm{Zn}_{1}\right)$ and $\left.30 \mathrm{~kg} \mathrm{P} / \mathrm{ha}+1.5 \mathrm{~g} \mathrm{Zn} / \mathrm{L}\right)$ $\left(\mathrm{P}_{30} \mathrm{Zn}_{1.5}\right)$ subplot with three replications. The plot size was $(1.8 \times 2 \mathrm{~m})$, having $45 \mathrm{~cm}$ distance between rows and $20 \mathrm{~cm}$ between plants and $15 \mathrm{~kg}$ per ha of nitrogen fertilizer was applied uniformly to all treatments as starter.

Agronomic data including seed yield, days to $50 \%$ flowering, $50 \%$ maturity, number of pods per plant, pod yield, number of seeds per pod and 100 seed weight (g), were collected following standard procedures. The data were analysis using GenStat 14th Edition statistical package (Payne 2014). Means were compared with Duncan's Multiple Range Tests at 5\% level. Bivariate correlation was used to test the relationship between the traits of groundnut. Sample of a seed for analysis of nutritional content of the seed (crud protein and fat content \%) was taken from the seed yield per plot to analysis according to AOAC (1995). Partial budget analysis of groundnut were conducted following International Maize and Wheat Improvement Center (CIMMYT) manual (CIMMYT 1988).

Table 1 Description of the genotypes used in the study

\begin{tabular}{llll}
\hline Genotypes & Status & Source & Color \\
\hline ICGV00308 $\left(\mathrm{G}_{1}\right)$ & Advanced line & ICRISAT-Mali & Light white \\
ICGV91114 $\left(\mathrm{G}_{1}\right)$ & Advanced line & ICRISAT-Mali & Light white \\
Standard check (sedi) & Released variety & Melka-Werer ARC & Light red \\
\hline
\end{tabular}




\section{Result and discussion}

\section{Selected physicochemical properties of the study site}

The soil texture of the experimental area was appeared to be loamy sand (Table 2). Therefore, the soil texture of the study place is appropriate for groundnut production as the crop is grown mostly on light-textured soils ranging from coarse and fine sands to sandy clay loams. The total nitrogen content, available $\mathrm{P}$ and organic matter of the experimental site were $0.07 \%, 7.72 \mathrm{ppm}$ and $0.09 \%$

Table 2 Some Physicochemical properties of the soil at the experimental field

\begin{tabular}{lll}
\hline Properties & Values & Remark \\
\hline Soil physical properties & & \\
Sand (\%) & 88 & \\
Clay (\%) & 4 & \\
Silt (\%) & 8 & \\
Soil texture & & Loamy sand \\
Soil chemical properties & & \\
pH (by 1:2.5 soil water ratio) & 7.25 & Almost neutral \\
Total nitrogen (\%) & 0.07 & Very low \\
Organic carbon (\%) & 0.09 & Very low \\
Available phosphorus (ppm) & 7.72 & Very low \\
Available Zn (ppm) & 5.52 & Very low \\
Cation exchange capacity (cmol(+)/kg/ha) & 2.7 & Very low \\
Electrical conductivity (ms/cm) & 0.045 & Very low \\
\hline
\end{tabular}

Mekelle soil laboratory (2017), as described by Landon (1991) respectively, which was very low to support the growth of plant. The $\mathrm{pH}$ value of the experimental site 7.25 was almost neutral according Tekalign (1991) within the ideal $\mathrm{pH}$ range value for groundnut production. Results of cation exchange capacity and electrical conductivity $(2.7$ $\mathrm{cmol}(+) / \mathrm{kg} / \mathrm{ha})$ and $(0.045 \mathrm{~ms} / \mathrm{cm})$ respectively were very low to groundnut cultivation (Landon 1991) and it implied that the soil have low holding exchanging cations but free of salt problem. Results of potassium $238 \mathrm{~kg} / \mathrm{ha}$ was rated optimum for well growth of the crop (Landon 1991). The level of available Zinc ( $\mathrm{Zn})$ in the experimental site was found to be $5.52 \mathrm{ppm}$ which is very low to groundnut production.

\section{Effects on phenological and growth traits of groundnut}

The analysis of variance revealed a significant $(\mathrm{p}<0.05)$ genotype and fertilizer main effects for days to $50 \%$ flowering. The Sedi variety appeared to flower earlier (35 days) followed by genotype ICGV91114 (36 days). While, the genotype coded as ICGV0308 flowered late (37 days) (Fig. 1). Similar study by Sastry et al. (1985) stated that groundnut genotypes, which flower early during first and the second week of the flowering period produce better yield. The differences observed among the groundnut genotypes in relation to days to flowering can be attributed to the difference in growth characteristics among the genotypes. Verma et al. (2009) reported variable growth patterns in some groundnut genotypes, which could be due to differences in their genetic makeup. The

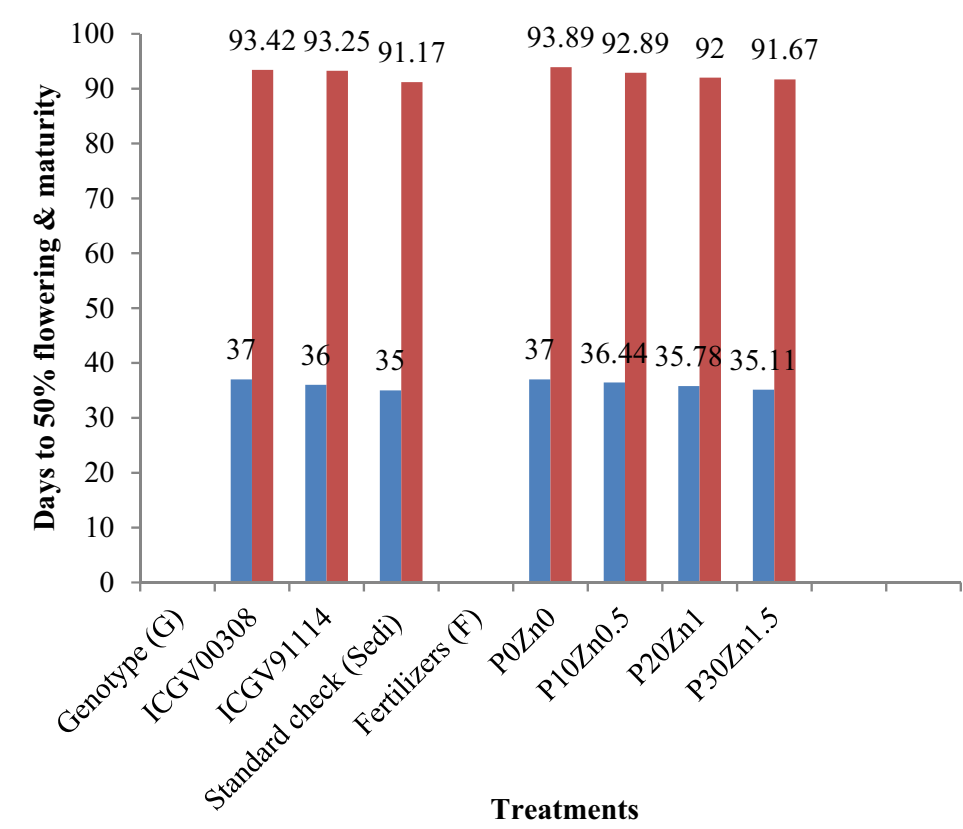

Days to $50 \%$ flowering

- Days to $50 \%$ maturity

Treatments

Fig. 1 Effect of groundnut genotypes and PZn fertilizer on Phenology of groundnut 
main effect of combined phosphorus and foliar spray of zinc also showed significant effect on flowering. That combination may improve utilization of nutrients and water, which reflected on good growth and biological yield.

There was no interaction effect between genotype and fertilizer on between $50 \%$ maturity. The main effect of genotypes and fertilizer showed a significant difference for days to $50 \%$ maturity. The groundnut genotypes showed a significant difference for days to maturity where the Sedi matures relatively earlier than genotype ICGV91114 and ICGV00308 (Fig. 1). Days to maturity showed a similar pattern with days to flowering with the application of combined fertilizer. The shortest maturity day was recorded from the highest rate.

Analysis of variance indicated that, neither the main effect nor the interaction effect was no significant difference on the leaf width.

ANOVA table revealed that application of combined PZn fertilizer wes a significance effect $(\mathrm{p}<0.05)$ on leaf length. While the genotype main effect and interaction was no significant effects. The highest length was achieved at the maximum rate of $\mathrm{P}_{30} \mathrm{Zn}_{1.5}$ fertilizer (Fig. 2). The average leaf length in the control plots was relatively lower than the treated plots. Increasing the joint application of phosphorus with foliar zinc up to $\mathrm{P}_{30} \mathrm{Zn}_{1.5}$ was increasing the leaf length on Sedi variety. In line with current study, Gobarah et al. (2006) reported that increasing P fertilization up to $60 \mathrm{~kg} \mathrm{P}_{2} \mathrm{O}_{5} /$ fad with zinc concentration up to $1 \mathrm{~g} / \mathrm{L}$ improves leaf length. These effects revealed that foliar nutrition of groundnut with zinc might increase the efficiency phosphorus utilization and enhancing vegetative growth.

\section{Effects on yield and yield components}

The fertilizer main effect and interaction effects were statistically significant $(\mathrm{p}<0.01)$ for number of pods per plant. The highest number of pods per plant (35.4) was recorded from the interaction of genotype ICGV00308 with $\mathrm{P}_{30} \mathrm{Zn}_{1.5}$ at par with $\mathrm{P}_{20} \mathrm{Zn}_{1}$ (Table 3). This genotype (ICGV00308) depicted a relatively lower performance in average number of pods per plant (23.13) without fertilizer.

A statistically significant main and interaction effects were showed on pod yield $(\mathrm{p}<0.01)$. The highest pod yield was attended from the higher rate of fertilizer with sedi variety. Whereas the lowest pod yield was recorded

Table 3 The interaction effect of genotypes and PZn fertilizer on pod number/plant

\begin{tabular}{llllll}
\hline Genotypes (G) & \multicolumn{5}{l}{ Combined fertilizers (F) } \\
\cline { 2 - 6 } & $\mathbf{P}_{\mathbf{0}} \mathbf{Z n}_{\mathbf{0}}$ & $\mathbf{P}_{\mathbf{1 0}} \mathbf{Z n}_{\mathbf{0 . 5}}$ & $\mathbf{P}_{\mathbf{2 0}} \mathbf{Z n}_{\mathbf{1}}$ & $\mathbf{P}_{\mathbf{3 0}} \mathbf{Z n}_{\mathbf{1 . 5}}$ & Mean \\
\hline ICGV00308 & 23.13 & 31.27 & 33.20 & 35.40 & 30.75 \\
ICGV91114 & 28.07 & 30.27 & 31.00 & 30.73 & 30 \\
Standard check (sedi) & 28.13 & 29.40 & 30.50 & 32.73 & 30.19 \\
Mean & 26.4 & 30.3 & 31.6 & 33 & \\
LSD(0.05) GXF & 2.15 & & & & \\
CV (\%) GXF & 4.2 & & & & \\
\hline
\end{tabular}

$\mathrm{P}=\mathrm{kg} / \mathrm{ha} \mathrm{Zn}=\mathrm{g} / \mathrm{L}, \mathrm{LSD}(0.05)=$ least significant difference at $5 \%$ level; $\mathrm{CV}=$ coefficient of variation

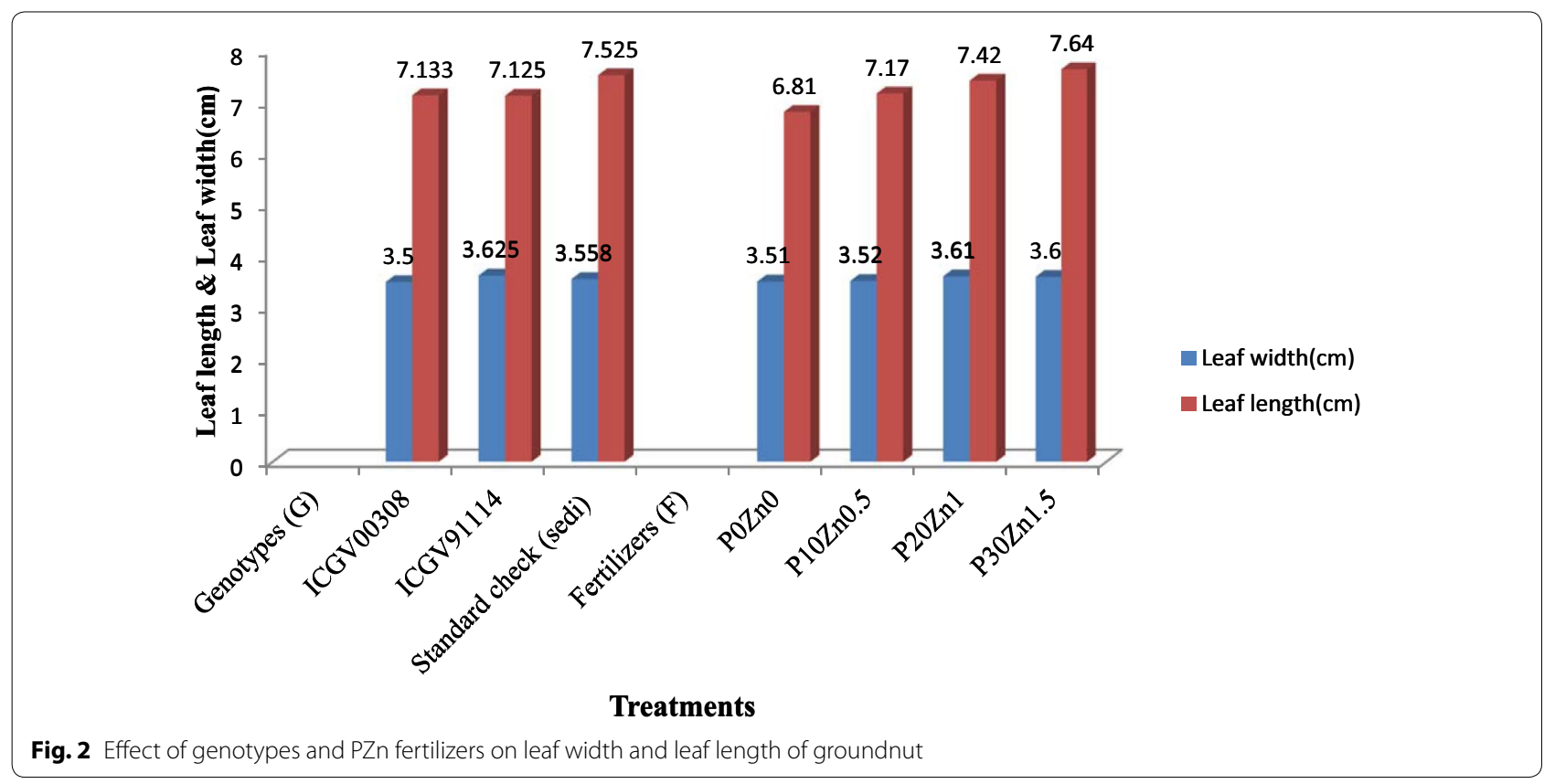


from ICGV00308 genotype without fertilizer (control) (Table 4).

Analysis of variance showed that, there were a significant main and interaction effects on number of seeds per pod. The result exhibited that, the highest number of seeds per pod was obtained from Sedi variety with $\mathrm{P}_{30} \mathrm{Zn}_{1.5}$ fertilizer (Table 5). While the lowest number of seeds per pod was recorded from the genotype ICGV00308 with $\mathrm{P}_{20} \mathrm{Zn}_{1}$ fertilizer. This is may be due to the genetic makeup of the genotype and/or effect of the combined fertilizer.

There were a significant interaction and main effect of groundnut and fertilizer on seed yield of groundnut $(\mathrm{p}<0.01)$. The highest seed yield $(2529 \mathrm{~kg} / \mathrm{ha})$ and $(2516 \mathrm{~kg} / \mathrm{ha})$ was obtained from variety Sedi with $\mathrm{P}_{30} \mathrm{Zn}_{1.5}$ and $\mathrm{P}_{20} \mathrm{Zn}_{1}$ combined fertilizer rate, respectively (Table 6).

While the lowest seed yield $(1908 \mathrm{~kg} / \mathrm{ha})$ was recorded from ICGV00308 genotype without fertilizer. The highest recorded seed yield increment over this treatment was $33 \%$. Under this treatment significant increase in seed yield may be due to associated improvement in leaf length, leaf width, pod number/plant, pod yield/ha and number of seeds/pods as reported by Jeetarwal (2013). The seed yield has a highly significant and positive correlation with those yield attributes that further support their direct and indirect effect on seed yield in consistency with the report of Bethlehem (Seed yield and quality of groundnut (Arachis hypogaea L.), unpublished M.Sc. thesis, Haramaya University, Ethiopia).

Application of combined fertilizers on sedi variety was increase productivity of groundnut per unite area from the current farmers yield of Tanqua-Abergelle $(1200 \mathrm{~kg} / \mathrm{ha})$ which is very low compare to the yield obtained from the current research finding $2529 \mathrm{~kg} /$ ha that proved more than double yield advantage than the farmers practice in the Woreda. Thus, result also exhibited promising increment than the average yield

Table 4 Interaction effect of genotypes and PZn on pod yield $\mathrm{kg} / \mathrm{ha}$ of groundnut

\begin{tabular}{llllll}
\hline Genotypes (G) & \multicolumn{5}{l}{ Combined fertilizers (F) } \\
\cline { 2 - 6 } & $\mathbf{P}_{\mathbf{0}} \mathbf{Z n}_{\mathbf{0}}$ & $\mathbf{P}_{\mathbf{1 0}} \mathbf{Z n}_{\mathbf{0 . 5}}$ & $\mathbf{P}_{\mathbf{2 0}} \mathbf{Z n}_{\mathbf{1}}$ & $\mathbf{P}_{\mathbf{3 0}} \mathbf{Z n}_{\mathbf{1 . 5}}$ & Mean \\
\hline ICGV00308 & 2904 & 3072 & 3198 & 3302 & 3119 \\
ICGV91114 & 3059 & 3028 & 3180 & 3135 & 3101 \\
Standard check (sedi) & 3341 & 3302 & 3475 & 3567 & 3421 \\
Mean & 3101 & 3134 & 3284 & 3335 & \\
LSD (0.05) GXF & 237.3 & & & & \\
CV (\%) GXF & 3.5 & & & & \\
\hline
\end{tabular}

$\mathrm{P}=\mathrm{kg} / \mathrm{ha} \mathrm{Zn}=\mathrm{g} / \mathrm{L}, \mathrm{LSD}(0.05)=$ least significant difference at $5 \%$ level $\mathrm{CV}=$ coefficient of variation
Table 5 The interaction effect of genotypes and PZn fertilizer on number of seeds/pod

\begin{tabular}{llllll}
\hline Genotypes (G) & \multicolumn{6}{l}{ Combined fertilizers (F) } \\
\cline { 2 - 6 } & $\mathbf{P}_{\mathbf{0}} \mathbf{Z n}_{\mathbf{0}}$ & $\mathbf{P}_{\mathbf{1 0}} \mathbf{Z n}_{\mathbf{0 . 5}}$ & $\mathbf{P}_{\mathbf{2 0}} \mathbf{Z n}_{\mathbf{1}}$ & $\mathbf{P}_{\mathbf{3 0}} \mathbf{Z n}_{\mathbf{1 . 5}}$ & Mean \\
\hline ICGV00308 & 2 & 1.80 & 1.67 & 1.73 & 1.8 \\
ICGV91114 & 1.87 & 1.93 & 1.87 & 2.07 & 1.94 \\
Standard check(Sedi) & 2.33 & 2.67 & 2.67 & 2.87 & 2.64 \\
Mean & 2.06 & 2.13 & 2.07 & 2.22 & \\
LSD(0.05) GxF & 0.23 & & & & \\
CV (\%) GxF & 6.3 & & & & \\
\hline
\end{tabular}

$\mathrm{P}=\mathrm{kg} / \mathrm{ha} \mathrm{Zn}=\mathrm{g} / \mathrm{L}, \mathrm{LSD}(0.05)=$ least significant difference at $5 \%$ level; $\mathrm{CV}=$ coefficient of variation

(700 kg/ha) of the region Tigray and $1330 \mathrm{~kg} / \mathrm{ha}$ of the national productivity (CSA (Central Statistics Agency) 2014). This result is maybe due to the foliar application of zinc with $\mathrm{P}$ at the depleted soil supports to this yield.

Results showed that main effect of fertilizer rates and interaction effects were statistically significant $(\mathrm{p}<0.005)$ effect on shelling percentage. The highest shelling percentage (73.33) was recorded form genotype ICGV91114 with $\mathrm{P}_{30} \mathrm{Zn}_{1.5}$ fertilizer. The lowest shelling percentage was record form genotype ICGV00308 (65.68\%) percentage without fertilizer (Fig. 3) and It has a positive correlation with seed yield $(r=0.62)$ and this was may be due to the application of more fertilizer to the soil and foliar, which enhances these parameters.

Hundred seed weight was significantly $(\mathrm{p}<0.05)$ influenced by the genotype main effect. However, the fertilizer main effect and the interaction component were not significant. The genotype coded as ICGV91114 had relatively higher mean seed weight $(47.23 \mathrm{~g})$ than the other genotypes in the finding (Fig. 4). This result is may be due to the genetic differences between the genotypes that is consistent with the idea of Mulatu (2014) who stated that the seed weight characters is more influenced by genetic factors than environment.

Table 6 Seed yield (kg/ha) as affected by interaction of genotypes and PZn fertilizers

\begin{tabular}{llllll}
\hline Genotypes (G) & \multicolumn{5}{l}{ Combined fertilizers (F) } \\
\cline { 2 - 6 } & $\mathbf{P}_{\mathbf{0}} \mathbf{Z n}_{\mathbf{0}}$ & $\mathbf{P}_{\mathbf{1 0}} \mathbf{Z n}_{\mathbf{0 . 5}}$ & $\mathbf{P}_{\mathbf{2 0}} \mathbf{Z n}_{\mathbf{1}}$ & $\mathbf{P}_{\mathbf{3 0}} \mathbf{Z n}_{\mathbf{1 . 5}}$ & Mean \\
\hline ICGV00308 & 1908 & 2205 & 2326 & 2378 & 2204 \\
ICGV91114 & 2204 & 2201 & 2221 & 2296 & 2230 \\
Standard check(sedi) & 2351 & 2384 & 2516 & 2529 & 2445 \\
Mean & 2154 & 2263 & 2354 & 2401 & \\
LSD(0.05) GXF & 170.8 & & & & \\
CV (\%) GxF & 4.4 & & & & \\
\hline
\end{tabular}

$\mathrm{P}=\mathrm{kg} / \mathrm{ha} \mathrm{Zn}=\mathrm{g} / \mathrm{L}, \mathrm{LSD}(0.05)=$ Least significant difference at $5 \%$ level; $\mathrm{CV}=$ coefficient of variation 


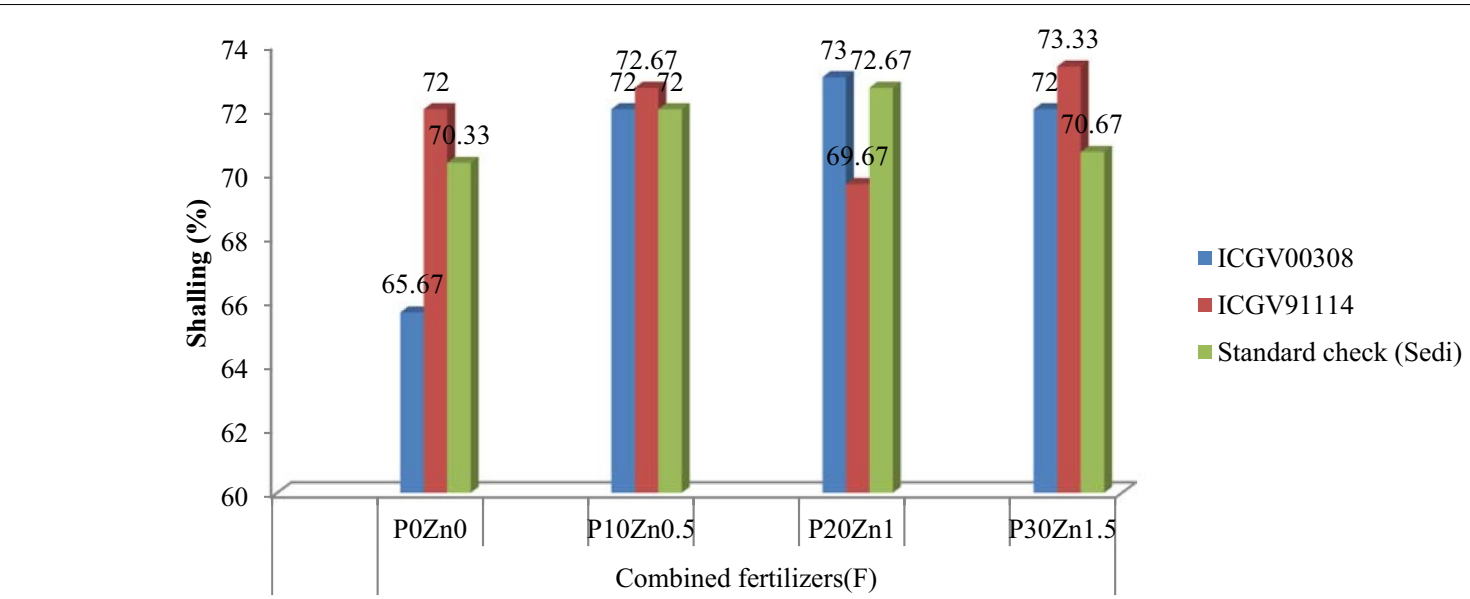

Fig. 3 The interaction effect of genotypes and PZn fertilizer on shelling percentage of groundnut

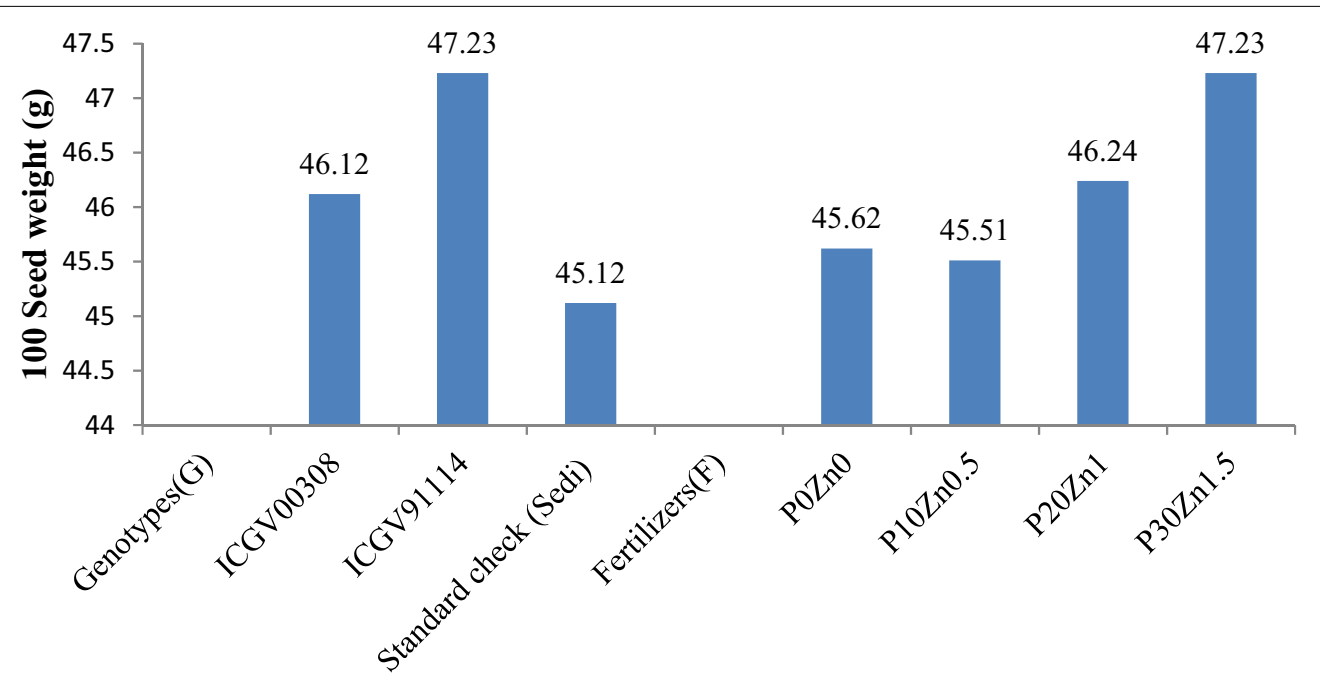

Treatments

Fig. 4 Main effect of genotypes and PZn on hundred seed weight of groundnut

In other hand, hundred seed weight (45.12 g) of the genotype had found in the rage of 35-70 $\mathrm{g}$ is under the rage, which fulfills the international market quality of seed grade (Acland 1971).

\section{Effects on seed nutrition content}

The main effect fertilizer level and the interaction effects were statistically highly significant $(p<0.01)$ for crude protein content. The maximum protein content $(37.79 \%)$ was recorded from sedi variety at the rate of $\mathrm{P}_{30} \mathrm{Zn}_{1.5}$ fertilizer. Nevertheless, the lowest protein content was also recorded from the same variety (Sedi) in the lowest rate of fertilizer (Table 7).
Table 7 The interaction effect of genotypes and PZn fertilizers on protein content (\%)

\begin{tabular}{lccccc}
\hline Genotypes (G) & \multicolumn{7}{l}{ Combined fertilizers (F) } \\
\cline { 2 - 6 } & $\mathbf{P}_{\mathbf{0}} \mathbf{Z n}_{\mathbf{0}}$ & $\mathbf{P}_{\mathbf{1 0}} \mathbf{Z n}_{\mathbf{0 . 5}}$ & $\mathbf{P}_{\mathbf{2 0}} \mathbf{Z n}_{\mathbf{1}}$ & $\mathbf{P}_{\mathbf{3 0}} \mathbf{Z n}_{\mathbf{1 . 5}}$ & Mean \\
\hline ICGV00308 & 36.78 & 37.25 & 37.46 & 37.46 & 37.24 \\
ICGV91114 & 37.13 & 37.10 & 36.65 & 37.03 & 36.98 \\
Standard check (Sedi) & 36.69 & 35.90 & 37.36 & 37.79 & 36.94 \\
Mean & 36.87 & 36.75 & 37.16 & 37.43 & \\
LSD (0.05) GXF & 0.69 & & & & \\
CV (\%) GXF & 1.1 & & & & \\
\hline
\end{tabular}

$\mathrm{P}=\mathrm{kg} / \mathrm{ha} \mathrm{Zn}=\mathrm{g} / \mathrm{L}, \mathrm{LSD}(0.05)=$ least significant difference at $5 \%$ level; $\mathrm{CV}=$ coefficient of variation 
The analysis variance showed fat content was exhibited a significant main effect and the interaction effects. The highest percentage of fat content (43.95\%) was extracted from ICGV00308 under the highest level of fertilizer $\left(\mathrm{P}_{30} \mathrm{Zn}_{1.5}\right)$ (Table 8). While, the lowest fat content was gained from Sedi at untreated condition $\left(\mathrm{P}_{0} \mathrm{Zn}_{0}\right)$. The significant interaction effects of genotype and fertilizer on crude protein and fat (\%) were found in the range of $36.69-37.79$ and $41.44-43.95 \%$ by the application of $\mathrm{P}_{30} \mathrm{Zn}_{1.5}$ fertilizer on Sedi and ICGV00308, respectively. As the rate of fertilizer increases, the percentage of crude protein and fat content tend to increase linearly. Okello et al. (2010) who found $20-50 \%$ and $40-50 \%$ protein and fat content on groundnut due to fertilizer application, respectively reported similar finding. The current result was in line with Majumdar et al. (2001) also reported that, the percentage of protein increase as a result of an application of phosphorus up to $70 \mathrm{~kg} \mathrm{P}_{2} \mathrm{O}_{5} / \mathrm{ha}$. Gobarah et al. (2006) also noted that $\mathrm{P}$ application significantly

Table 8 The interaction of genotypes and PZn fertilizer on fat content (\%) of groundnut

\begin{tabular}{lclllll}
\hline Genotypes & \multicolumn{5}{l}{ Combined fertilizers } & \\
\cline { 2 - 5 } & $\mathbf{P}_{\mathbf{0}} \mathbf{Z} \mathbf{n}_{\mathbf{0}}$ & $\mathbf{P}_{\mathbf{1 0}} \mathbf{Z n}_{\mathbf{0 . 5}}$ & $\mathbf{P}_{\mathbf{2 0}} \mathbf{Z n}_{\mathbf{1}}$ & $\mathbf{P}_{\mathbf{3 0}} \mathbf{Z n}_{\mathbf{1 . 5}}$ & Mean \\
\hline ICGV00308 & 43.67 & 43.76 & 43.91 & 43.95 & 43.81 \\
ICGV91114 & 42.03 & 41.45 & 41.71 & 43 & 42.04 \\
Standard check(sedi) & 41.78 & 41.93 & 43.63 & 42.9 & 42.56 \\
Mean & 42.49 & 41.71 & 43.08 & 43.28 & \\
LSD (0.05) GXF & 0.71 & & & & \\
CV (\%) GXF & 1 & & & & \\
\hline
\end{tabular}

$\mathrm{P}=\mathrm{kg} / \mathrm{ha} \mathrm{Zn}=\mathrm{g} / \mathrm{L}, \mathrm{LSD}(0.05)=$ least significant difference at $5 \%$ level; $\mathrm{CV}=$ coefficient of variation increased protein $(25.82 \%)$ contents on groundnut over control.

\section{Associations among the groundnut parameters}

A bivariate correlation analysis between the measured traits had positive and negative associations (Table 9). Seed yield had a strong and positive correlation with pod yield $(r=0.936)$, leaf length $(0=0.927)$, pod number/plant $(r=0.683)$, shelling percentage $(r=0.616)$ and number seeds/pod $(r=0.576)$. Nevertheless, days to $50 \%$ flowering and days to $50 \%$ maturity were negatively correlated with seed yield, $(\mathrm{r}=-0.833)$ and $(\mathrm{r}=-0.91)$, respectively.

\section{Partial budget analysis}

Partial budget analysis of the interaction effect showed that highest marginal rate of return $(380.58 \%)$ was obtained from the ICGV00308 genotype at the application of $\mathrm{P}_{10} \mathrm{Zn}_{0.5}$ (Table 10). This rate of fertilizer application was economically above the minimum acceptable marginal rate of return (100\%) (CIMMYT 1988). This implies that for one birr invested in groundnut production, the producer can get 3.8 ETB.

\section{Conclusion and rcommendations}

The result of the current field experiment revealed encouraging response of the genotypes to combine $P$ and $\mathrm{Zn}$ application, which implied that those factors may the most limiting features in the loamy sand soil. The highest seed yield $(2529 \mathrm{~kg} / \mathrm{ha})$ obtained from variety Sedi receiving $\mathrm{P}_{30} \mathrm{Zn}_{1.5}$ fertilizer. The result of the current research would provide a useful insight for the smallholder farmers in the study area who often use the

Table 9 Correlation coefficients between the groundnut parameters as affected by genotypes and PZn combined fertilizers

\begin{tabular}{|c|c|c|c|c|c|c|c|c|c|c|c|c|}
\hline Parameters & DF (\%) & $\mathrm{LW}(\mathrm{cm})$ & $\mathrm{LL}(\mathrm{cm})$ & DM (\%) & PN/P & PY (kg/ha) & NS/P & S (\%) & SY (kg/ha) & HSW (g) & $\mathrm{CP}(\%)$ & $F(\%)$ \\
\hline DF (\%) & 1 & & & & & & & & & & & \\
\hline LW (cm) & -0.339 & 1 & & & & & & & & & & \\
\hline $\mathrm{LL}(\mathrm{cm})$ & $-0.737^{* *}$ & 0.474 & 1 & & & & & & & & & \\
\hline DM (\%) & $0.942^{* *}$ & -0.286 & $-0.824^{* *}$ & 1 & & & & & & & & \\
\hline $\mathrm{PN} / \mathrm{P}$ & -0.377 & 0.235 & $0.801^{* *}$ & -0.529 & 1 & & & & & & & \\
\hline PY (kg/ha) & $-0.874^{* *}$ & 0.175 & $0.821^{* *}$ & $-0.938^{* *}$ & 0.513 & 1 & & & & & & \\
\hline NS/P & $-0.788^{* *}$ & 0.114 & 0.408 & $-0.732^{* *}$ & -0.101 & $0.722^{* *}$ & 1 & & & & & \\
\hline S (\%) & -0.33 & $0.58^{*}$ & $0.674^{*}$ & -0.373 & $0.679^{*}$ & 0.305 & -0.001 & 1 & & & & \\
\hline SY (kg/ha) & $-0.833^{* *}$ & 0.371 & $0.927^{* *}$ & $-0.91^{* *}$ & $0.683^{*}$ & $0.936^{* *}$ & $0.576^{*}$ & $0.616^{*}$ & 1 & & & \\
\hline HSW(g) & 0.013 & 0.235 & 0.004 & 0.158 & 0.161 & -0.269 & -0.34 & $-0.47^{*}$ & -0.239 & 1 & & \\
\hline CP (\%) & -0.024 & 0.296 & 0.445 & -0.243 & 0.509 & 0.260 & -0.126 & 0.216 & 0.342 & -0.031 & 1 & \\
\hline$F(\%)$ & 0.112 & 0.033 & 0.186 & -0.033 & 0.252 & 0.056 & -0.186 & -0.067 & 0.049 & -0.094 & 0.542 & 1 \\
\hline
\end{tabular}

* and ** significant at $\mathrm{p}<0.05$ and $\mathrm{p}<0.01$, respectively and numbers with no * are non-significant. DF $(\%)=$ days to $50 \%$ flowering, LW (cm) $=$ leaf width, LL( $\mathrm{cm})=$ leaf length, DM $(\%)=$ days to $50 \%$ maturity, PN/P = pod Number/plant, PY $(\mathrm{kg} / \mathrm{ha})=$ Pod yield, NS/P = Number of seeds $/ \mathrm{pod}$, S\% $=$ shelling $\%$, SY $(\mathrm{kg} / \mathrm{ha})=\mathrm{Seed}$ yield, HSW $(\mathrm{g})=100$ seed $(\mathrm{g})$ weight $(\mathrm{g}), \mathrm{CP}=$ crude protein $(\%), \mathrm{F}(\%)=$ fat $(\%)$ 
Table 10 Partial budget analysis for groundnut genotypes and fertilizer treatments

\begin{tabular}{|c|c|c|c|c|}
\hline \multirow[t]{2}{*}{ ICGV00308 } & \multicolumn{4}{|c|}{ Fertilizers } \\
\hline & $\mathrm{P}_{0} \mathrm{Zn}_{0}$ & $P_{10} Z_{0.5}$ & $P_{20} Z n_{1}$ & $P_{30} Z_{1.5}$ \\
\hline Net returns (ETB/ha) & 42,930 & 48,222 & 50,017 & $50,259.5$ \\
\hline Total input cost (ETB/ha) & 0 & 1390.5 & 2318 & 3245.5 \\
\hline Domination rank & & ND & ND & ND \\
\hline Marginal benefit (ETB/ha) & 0 & 5292 & 1795 & 242.5 \\
\hline Marginal cost (Birr/ha) & 0 & 1390.5 & 927.5 & 927.5 \\
\hline MRR (\%) & & 380.58 & 193.53 & 26.15 \\
\hline \multirow[t]{2}{*}{ ICGV91114 } & \multicolumn{4}{|c|}{ Fertilizers } \\
\hline & $P_{0} Z n_{0}$ & $P_{10} Z_{0.5}$ & $P_{20} Z n_{1}$ & $P_{30} Z n_{1.5}$ \\
\hline Net returns (ETB/ha) & 49,590 & 48,132 & $47,654.5$ & $48,414.5$ \\
\hline Total input cost (ETB/ha) & 0 & 1390.5 & 2318 & 3245.5 \\
\hline Domination rank & & $\mathrm{D}$ & $\mathrm{D}$ & $\mathrm{D}$ \\
\hline \multirow[t]{2}{*}{ Sedi } & \multicolumn{4}{|c|}{ Fertilizers } \\
\hline & $\mathrm{P}_{0} \mathrm{Zn}_{0}$ & $P_{10} Z n_{0.5}$ & $P_{20} Z_{1}$ & $P_{30} Z_{1.5}$ \\
\hline Net Returns (Birr/ha & $52,897.5$ & $52,249.5$ & 54,292 & 53,657 \\
\hline Total input cost (ETB/ha) & 0 & 1390.5 & 2318 & 3245.50 \\
\hline Domination rank & & $\mathrm{D}$ & ND & $\mathrm{D}$ \\
\hline Marginal benefit (ETB/ha) & 0 & & 1394.50 & \\
\hline Marginal cost (ETB/ha) & 0 & & 2318 & \\
\hline MRR (\%) & & & 60.16 & \\
\hline
\end{tabular}

The value written by italic indicated the highest MRR\%

$\mathrm{D}=$ dominated treatment; $\mathrm{ND}=$ non dominated; $\mathrm{P}=\mathrm{kg} / \mathrm{ha} ; \mathrm{Zn}=\mathrm{g} / \mathrm{L}, \mathrm{ETB}=$ Ethiopian Birr

blanket recommendations of the common fertilizers such as Urea and DAP for all crops including groundnut. The highest percentage of fat and protein were extracted from ICGV00308 and sedi at the highest fertilizer rate $\left(\mathrm{P}_{30} \mathrm{Zn}_{1.5}\right)$, respectively. From economic point of view, the highest MRR (380.58\%) was obtains from the application $\mathrm{P}_{10} \mathrm{Zn}_{0.5}$ fertilizer with ICGV00308 genotype. Thus, based on the finding, it can be concluded that genotype ICGV00308 at $\mathrm{P}_{10} \mathrm{Zn}_{0.5}$ fertilizer was the most economically attractive option for the farmers in the study area and similar agro ecologies. Further field experiment as well as laboratory analysis should be conduct by incorporating more genotypes over location.

\section{Acknowledgements}

My first and foremost thanks go to my advisor's Dr. Dereje Assefa and Dr. Yemane Tsehaye for their guidance and constructive comments starting from the idea of proposal writing up to the final stage with sharing me their accumulated professional experience with kind approach. I am highly thankful to Tigray Agricultural Research Institute (TARI) and NORHED-Sweet Potato Project for financial support.

\section{Authors' contributions}

HM designed the study and collect data, analyzed the data and drafted the manuscript, DA contributed to review the first draft of the manuscript and YTS also contributed to review the second draft of the manuscript. All authors read and approved the final manuscript.

\section{Funding}

Tigray Agricultural Research Institute.

Availability of data and materials

Not applicable.

Ethics approval and consent to participate

Not applicable.

\section{Consent for publication}

Not applicable.

\section{Competing interests}

The author declares no competing interests.

\section{Author details}

${ }^{1}$ Tigray Agricultural Research Institute, Abergelle Agricultural Research Center, Tigray, P. O. Box 44, Abi-Adi, Ethiopia. ${ }^{2}$ College of Dryland Agriculture and Natural Resources, Department of Crop and Horticultural Science, Mekelle University, Tigray, P.O. Box 231 Mekelle, Ethiopia.

Received: 1 May 2020 Accepted: 17 October 2020

Published online: 06 November 2020

\section{References}

Acland JD (1971) Groundnuts East African crops. Food and Agriculture Organization, Rome

Adinya IB, Enun EE, ljoma JU (2010) Exploring profitability potentials in groundnut production through agroforestry practices: a case study in Nigeria. J Anim Plant Sci 20(2):123-131 
AOAC (1995) Official methods of analysis, 16th edn., Sec. 975.55. AOAC International, Arlington, VA

Baraker B, Jha SK, Wani SP, Garg KK (2017) Effect of balanced fertilizer management practices on factor of productivity on Groundnut (Arachis hypogaea L.) Cultivation. Int J Chem Stud 5(4):1288-1291

Bouyoucos J (1962) Hydrometer method improved for making particle size analysis of soil. Agron J 54:464-465

Bremner JM, Mulvaney CS (1982) Nitrogen-Total. In: Page AL, Miller RH, Keeney DR (eds) Methods of soil analysis. Part 2-Chemical and microbiological properties, 9.2. American Society of Agronomy, Madison, WI, pp 595-624

CIMMYT (1988) From agronomic data to farmer recommendations: an economics training manual, Completely revised edition. In: DF conference held at International Livestock Centre for Africa (ILCA), Mexico, 31 August-4 September 1987

CSA (Central Statistics Agency) (2014) Report on Area and Production of Major Crops (Private Peasant Holdings, Meher Season): Agricultural Sample Survey. Central Statistics Agency, Addis Ababa

Daniel E (2009) Groundnut research. In: Presentation for workshop (pp. 1-3). Ethiopia: Werer Agricultural Research Center

Dordas C (2008) Role of nutrients in controlling plant diseases in sustainable agriculture: a review. In: Lichtfouse E et al (eds) Sustainable agriculture, agronomic sustainable development, vol 28, pp 33-46

Gezahagn K (2013) Economics of Groundnut Production in East Hararghe Zone of Oromia Regional State, Ethiopia. Sci Technol Arts Res 2(2):135-139

Gobarah ME, Mohamed MH, Tawfik MM (2006) Effect of phosphorus fertilizer and foliar spraying with zinc on growth, yield and quality of groundnut under reclaimed sandy soils. J Appl Sci Res 2(8):491-496

Jeetarwal RL (2013) Response of groundnut (Arachis hypogaea L.). unpublished M.Sc. thesis Swami Keshwanand Rajasthan Agricultural

Landon JR (1991) Booker tropical soil manual. A hand book for soil survey and agricultural land evaluation in the tropics and sub tropics. Longman Publishers, New York, p 474
Majumdar B, Venkatesh MS, Lal B, Kumar K, Singh CS (2001) Effect of phosphorus and zinc nutrition on groundnut in an acid hapludalf of Meghalaya. Ann Agric Res 22(3):354-359

Mulatu Y (2014) Effect of planting density on growth, yield, and yield. Unpublished M.Sc. Thesis

Okello DK, Biruma M, Deom CM (2010) Overview of groundnuts research in Uganda: past, present and future. Afr J Biotechnol 9(39):6448-6459

Olsen R, Cole S, Watanabe F, Dean L (1954) Estimation of available phosphorus in soils by extraction with sodium bicarbonate. United States Department of Agriculture Circ. 939

Payne M (2014) Modern social work theory (Palgrave Macmillan)

Rhoades JD (1982) In methods of soil analysis. In: Miller ALP, Keeney DR (eds) American society of agronomy, Part 2, 2nd edn. Madison, USA

Sastry KSK, Chari M, Prasad TG (1985) Flowering pattern and pod development in bunch types of groundnut: is there a relationship between synchrony in flowering and pod development. Indian J Plant Physiol 28:64-71

Tekalign M (1991) Soil, plant, water, fertilizer, animal manure and compost analysis. Working Document No. 13. International Livestock Research Center for Africa, Addis Abab

Verma A, Malik CP, Sinsinwar YK, Gupta VK (2009) Yield parameter responses in a spreading (cv.M-13) and semi-spreading (cv.Girnar-2) types of groundnut to six growth regulators. Am Euras J Agric Environ Sci 6(1):88-91

Walkley A, Black IA (1934) An examination of the Degtjareff method for determining soil organic matter, and a proposed modification of the chromic acid titration method. Soil Sci 37(1):29-38

\section{Publisher's Note}

Springer Nature remains neutral with regard to jurisdictional claims in published maps and institutional affiliations.

\section{Submit your manuscript to a SpringerOpen ${ }^{\circ}$ journal and benefit from:}

- Convenient online submission

- Rigorous peer review

- Open access: articles freely available online

- High visibility within the field

- Retaining the copyright to your article

Submit your next manuscript at $\boldsymbol{\nabla}$ springeropen.com 